\title{
Determination of physico-chemical parameters and heavy metals in water samples from Itaogbolu area of Ondo-State, Nigeria
}

\author{
S. O. Adefemi and E. E. Awokunmi \\ Department of Chemistry, University of Ado Ekiti, P. M. B. 5363, Nigeria.
}

Accepted 22 December, 2009

\begin{abstract}
Water samples from selected hand-dug wells and Ona River in Itaogbolu area of Akure, Ondo State, Nigeria were collected, physico-chemical parameters and heavy metals were determined using standard analytical procedure. The results of the physico-chemical analysis were obtained in the following range; $\mathrm{PH}(6.59-7.68)$, temperature $\left(21.10-27.10^{\circ} \mathrm{C}\right)$, conductivity $(300-1150 \mu \Omega / \mathrm{cm})$, chloride $(78.10-$ $156.20 \mathrm{mg} / \mathrm{l})$, total hardness $(130-298 \mathrm{mg} / \mathrm{l})$, sulphate $(82.50-97.00 \mathrm{mg} / \mathrm{l})$, TDS $(0.02-0.09 \%)$ and alkalinity $(0.92-2.45 \mathrm{mg} / \mathrm{l})$. The highest value of physico-chemical parameters (compared with wells) was obtained in Ona River. The concentration of heavy metals $(\mathrm{mg} / \mathrm{l})$ in the well and Ona river samples were found in the following range; $\mathrm{Zn}$ (5.5-9.2), $\mathrm{Cr}$ (ND-0.4), $\mathrm{Pb}$ (ND-0.2), $\mathrm{Cu}$ (ND-0.4), $\mathrm{Ni}$ (ND-0.1) and $\mathrm{Fe}(0.1-5.3$ ). Cadmium was not detected at all in all water samples. The results obtained fell within the maximum allowable limit set by World Health Organization for drinking water except for water from Ona river.
\end{abstract}

Key words: Ona river, well water, physico-chemical parameters, heavy metals.

\section{INTRODUCTION}

The availability of good quality water is an indispensable feature for preventing diseases and improving quality of life (Oluduro and Aderiye, 2007). Natural water contains some types of impurities whose nature and amount vary with source of water. Metals for example, are introduced into aquatic system through several ways which include, weathering of rocks and leaching of soils, dissolution of aerosol particles from the atmosphere and from several human activities, including mining, processing and the use of metal based materials (Ipinmoroti and Oshodi, 1993; Adeyeye, 1994; Asaolu et al., 1997). Metals after entering the water many be taken up by fauna and flora and eventually, accumulated in marine organisms that are consumed by human being (Asaolu et al., 1997).

The increased use of metal-based fertilizer in agricultural revolution of the government could result in continued rise in concentration of metal pollutions in fresh water reservoir due to the water run-off. Also faecal pollution of drinking water causes water -born disease which has led to the death of millions of people both in cities and villages (Asaolu, 1998). The discharge of these wastes

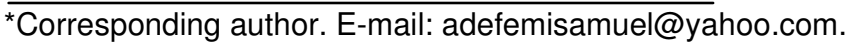

may affect the aquatic of such river or adversely and alter the chemical composition of the river (Adewoye, 1998).

Water quality characteristic of aquatic environment arise from a multitude of physical, chemical and biological interactions (Deuzane, 1979; Dee, 1989). The water bodies, rivers, lakes, dams and estuaries are continuously subject to dynamic state of change with respect to the geological age and geochemical characteristics. This is demonstrated by continuous circulation, transformation and accumulation of energy and matter through the medium of living thing and their activities. The dynamic balance in the aquatic ecosystem is upset by human activities, resulting in pollution which is manifested dramatically as fish kill, offensive taste, odour, colour and unchecked aquatic weeds.

Itaogbolu is located within Akure North local Government of Ondo State, South Western Nigeria. The town is a fast growing agrarian community apart from having a potential for booming business.

The study area has a land mass of $2940.109 \mathrm{~km}^{2}$ $4.30^{\circ}, 6.15^{\circ}, 5.45^{\circ}$ and $7.30^{\circ}$. The area has a relatively high relief of between 950 to $1500 \mathrm{~cm}$ above sea level.

Sociopolitical divisions bound Itaogbolu on the North by Ikere local Government in Ekiti State, on the West and East by Akure South and Owo local Government, 
Table 1. Detection limit of heavy metals for perkin model 306AA.

\begin{tabular}{cc}
\hline Metals & Detection limit \\
\hline $\mathrm{Zn}$ & .006 \\
$\mathrm{Cr}$ & .001 \\
$\mathrm{~Pb}$ & .004 \\
$\mathrm{Cd}$ & .004 \\
$\mathrm{Cu}$ & .001 \\
$\mathrm{Ni}$ & .005 \\
$\mathrm{Fe}$ & .003 \\
\hline
\end{tabular}

respectively, on the South by Idanre local Government.

Ona river and wells are major sources of water supply for the people of Itaogbolu area of Akure North local Government area, Ondo State, Nigeria. Water from these sources is used for drinking and other domestic purposes. This present study will provides information on the levels of heavy metals and physico-chemical parameters in these water sources to serve as baseline data for future studies.

\section{MATERIALS AND METHODS}

\section{Sampling}

Ten water samples (nine from ringed and un-ringed wells and one from Ona River) were taken from different locations in Itaogbolu area of Akure, Nigeria. The wells are selected from nine major quarters in the town while Ona river is located in their farm settlement. All samples were collected same day and kept in two litres rubber bottles, which have been previously washed with $10 \%$ $\mathrm{HNO} 3$ and $1: 1 \mathrm{HCl}$ for $48 \mathrm{~h}$. The rubber bottles were labeled and immediately few drops of $\mathrm{HNO}_{3}$ were added in order to prevent loss of metals, bacterial and fungal growth. Temperature and $\mathrm{PH}$ of water samples were also measured at the time of collection.

\section{Sample analysis}

Heavy metals were determined in water samples using a Perkin Elmer model 306 Atomic Absorption spectrophotometer (Detection limit of the heavy metal are shown in Table 1). The method used for the determination of physico-chemical parameters was described by A.O.A.C. (2005). The results were tabled for interpretation.

\section{Statistical analysis}

All data generated were analyzed statistically by calculating standard deviation, mean and coefficient of variation. The method used was described by Steel and Torrie (1960).

\section{RESULTS AND DISCUSSION}

The physico-chemical parameters obtained from analysis of water samples from wells and Ona River in Itaogbolu were presented in Table 2. In all water samples, the $\mathrm{PH}$ values ranged between 6.87-7.45 with an average value of $7.22 \pm 0.35$.The present results obtained for $\mathrm{P}^{\mathrm{H}}$ are similar to the results obtained by Adefemi et al. (2007) in water samples from Ureje, Egbe, Ero and Itapaji dams, all in Ekiti State. Asaolu (1997) also obtained similar results in water samples from Ondo State coastal water.

The temperature ranged between $25.10-27.10^{\circ} \mathrm{C}$ with an average value of $24.91 \pm 1.61^{\circ} \mathrm{C}$. The temperature of water sample from Ona River is higher than those obtained from wells. This could be due to increase in rate of chemical reaction and nature of biological activities, since temperature is one of the factors that govern the assimilative capacity of the aquatic system (EPA, 1976; Forstner and Wittlman, 1979).

On the average, the values of conductivity, chloride, total hardness, sulphate, total dissolved solid and alkalinity are: $834 \pm 256.66 \mu \Omega / \mathrm{cm}, 130.00 \pm 32.90 \mathrm{mg} / \mathrm{l}$, $167.40 \pm 50.25 \mathrm{mg} / \mathrm{l}, 74.55 \pm 11.56 \mathrm{mg} / \mathrm{l}, 0.04 \pm 0.02 \%$ and $1.52 \pm 0.52 \mathrm{mg} / \mathrm{l}$. A critical look at the results revealed that the values of these physico-chemical parameters are higher in Ona River than those obtained from wells. The quantity of waste in different phases of a natural aquatic system is reflected by the level of hardness, alkalinity, free $\mathrm{CO}_{2}$ and other physico-chemical parameters (EPA, 1976). Since the major occupation of people living in Itaogbolu is farming, the higher values of all these physico-chemical parameters than those obtained in wells could be as a result of washing away of sulphate based fertilizers into the river (Ipinmoroti and Oshodi, 1993; Vogel, 1970).

From the result in Table 3, zinc, chromium, lead, copper, nickel and iron were detected in most of the water samples. Zinc and iron were detected in all water samples while Cadmium was not detected at all in any of the samples.

The concentration of zinc ranged between $5.5-9.2 \mathrm{mg} / \mathrm{l}$ with an average value of $3.2 \pm 0.42 \mathrm{mg} / \mathrm{l}$. The highest concentration $(9.2 \mathrm{mg} / \mathrm{l})$ was obtained in Ona River. This could be associated with human activities such as the use of chemicals and zinc based fertilizers by farmers (Egila and Nimyel, 2002).

In addition to this, iron was found in all the water samples between $(0.1-5.3) \mathrm{mg} / \mathrm{l}$ with an average value of $0.71 \pm 0.22 \mathrm{mg} / \mathrm{l}$. The highest concentration $(5.3 \mathrm{mg} / \mathrm{l})$ Ona River compared with the values in wells is expected because it has been reported that iron occurs at high concentration in Nigeria soil (Asaolu et al., 1997; Asaolu and Olaofe, 2004; Nwajei and Gagophien, 2000).

On the average, the concentration of chromium $(0.2$ $\mathrm{mg} / \mathrm{l})$, lead $(0.12 \mathrm{mg} / \mathrm{l})$ copper $(0.18 \mathrm{mg} / \mathrm{l})$, nickel $(0.1$ $\mathrm{mg} / \mathrm{l}$ ) and all other heavy metals detected vary from one location to another. This could be attributed to geological distribution of minerals that vary from one location to the other. Similar variations were reported in sediment of major dams in Ekiti State (Adefemi et al., 2007).

In conclusion, physico-chemical parameters and levels of heavy metals in all the well water examined were consistent with World Health Organization standard for drinking water (WHO, 1982). In addition to this, it 
Table 2. The physico-chemical parameters of water samples from wells and Ona river in Itaogbolu.

\begin{tabular}{lcccccccc}
\hline \multicolumn{2}{l}{ Sample PH location } & $\begin{array}{c}\text { Temp. } \\
(\mathbf{o})\end{array}$ & $\begin{array}{c}\text { Conductivity } \\
(\boldsymbol{\mu} \mathbf{\Omega} / \mathbf{c m})\end{array}$ & $\begin{array}{c}\text { Chloride } \\
(\mathbf{m g} / \mathbf{l})\end{array}$ & $\begin{array}{c}\text { Total hardness } \\
(\mathbf{m g} / \mathbf{l})\end{array}$ & $\begin{array}{c}\text { Sulphate } \\
(\mathbf{m g} / \mathbf{l})\end{array}$ & $\begin{array}{c}\text { TDS } \\
(\%)\end{array}$ & $\begin{array}{c}\text { Alkalinity } \\
(\mathbf{m g} / \mathbf{l})\end{array}$ \\
\hline OR & 7.45 & 27.10 & 1150 & 156.20 & 298 & 97.00 & 0.09 & 2.45 \\
MRW1 & 7.68 & 25.00 & 650 & 127.80 & 166 & 78.00 & 0.05 & 0.95 \\
MRW2 & 7.32 & 24.00 & 750 & 156.20 & 128 & 60.00 & 0.03 & 1.60 \\
MURW & 6.93 & 21.10 & 300 & 78.10 & 150 & 60.00 & 0.04 & 1.05 \\
ETSRW & 7.02 & 25.40 & 710 & 113.60 & 182 & 77.50 & 0.04 & 1.10 \\
MRURW & 7.45 & 25.00 & 960 & 149.10 & 162 & 67.00 & 0.02 & 1.65 \\
ASRW1 & 7.61 & 26.00 & 950 & 127.80 & 184 & 67.00 & 0.02 & 1.75 \\
ASRW2 & 6.59 & 26.10 & 930 & 177.50 & 132 & 72.50 & 0.04 & 2.05 \\
AKSRW1 & 7.29 & 24.30 & 1000 & 141.00 & 142 & 83.50 & 0.06 & 1.70 \\
AKSRW2 & 6.87 & 25.10 & 940 & 78.10 & 130 & 82.50 & 0.02 & 0.92 \\
MEAN & 7.22 & 24.91 & 834 & 130.64 & 167.4 & 74.55 & 0.04 & 1.52 \\
SD & 0.35 & 1.61 & 252.66 & 32.90 & 50.25 & 11.56 & 0.02 & 0.51 \\
CV & 4.85 & 6.46 & 30.29 & 25.18 & 30.00 & 15.51 & 50.00 & 33.55 \\
\hline
\end{tabular}

Table 3. Concentration $(\mathrm{mg} / \mathrm{l})$ of heavy metals in water samples from wells and Ona River in Itaogbolu.

\begin{tabular}{llllllll}
\hline Sample location & $\mathbf{Z n}$ & $\mathbf{C r}$ & $\mathbf{P b}$ & $\mathbf{C d}$ & $\mathbf{C u}$ & $\mathbf{N i}$ & $\mathbf{F e}$ \\
\hline OR & 9.2 & 0.4 & 0.2 & ND & 0.4 & 0.1 & 5.3 \\
MRW1 & 0.9 & ND & 0.1 & ND & ND & ND & 0.2 \\
MRW2 & 0.7 & 0.1 & 0.1 & ND & ND & ND & 0.1 \\
MURW & 1.4 & 0.2 & 0.1 & ND & 0.1 & ND & 0.3 \\
ETSRW & 1.5 & ND & ND & ND & 0.1 & ND & 0.1 \\
MRURW & 2.1 & ND & ND & ND & ND & ND & 0.1 \\
ASRW1 & 4.7 & ND & ND & ND & ND & ND & 0.2 \\
ASRW2 & 3.2 & 0.2 & ND & ND & 0.2 & ND & 0.4 \\
AKSRW1 & 2.9 & ND & ND & ND & 0.1 & ND & 0.3 \\
AKSRW2 & 5.5 & 0.1 & 0.1 & ND & ND & ND & 0.1 \\
MEAN & 3.2 & 0.02 & 0.1 & - & 0.18 & 0.1 & 0.71 \\
SD & 0.4 & 0.01 & 0.02 & - & 0.01 & - & 0.22 \\
CV & 10.3 & 0.81 & 0.02 & - & 0.52 & - & 10.21 \\
\hline
\end{tabular}

Key: OR, Ona River; MRW1, market ring well 1; MRW2, market ring well 2; MURW, arket un-ringed well; ETSRW, Eja Ton Soro ringed wellM; MRURW, mission road un-ringed well; ASRW1, Alamo street ringed well1; ASRW2, Alamo street ringed well 2; AKSRW1, Akomowa Street ringed well 1; AKSRW2, Akomowa street ringed well 2; SD, standard deviation; CV, coefficient of variation.

important that bacteriological assessment of water from these different wells be carried out to be sure if the water is safe for drinking and other domestic applications.

\section{REFERENCES}

Adefemi OS, Asaolu SS, Olaofe O (2007). Assessment of the physicochemical Status of water samples from Major Dams in Ekiti State, Nigeria. Pak. Nut. 6(6) 657-659.
Adewoye RA (1998). Saving and Oceans; Opportunity for Nigeria Chemist: Plenary Address at $21^{\text {st }}$ Annual Int. Conf. Chemical Society Nig., at Conf. Centre, Univ. Ibadan p. 12.

Adeyeye El (1994). Determination of heavy metals in Illisha Africana, associated Water, Soil Sediments from some fish ponds. Int. J. Environ. Stud. 45: 231-240.

Asaolu SS, Ipinmoroti KO, Adeyinowo CE, Olaofe O (1997). Interrelationship of heavy metals concentration in water, sediment as fish samples from Ondo State coastal Area, Nig. Afr. J. Sci 1: 55-61.

Asaolu SS (1998).Chemical Pollution Studies of Coastal Water of Ondo State. Ph.D Thesis, Fed. Univ. Technol., Akure. (Unpublished). 
148 Afr. J. Environ. Sci. Technol.

Asaolu SS, Olaofe O (2004). Biomagnification factors of some heavy and essential metals in sediments, fish and crayfish from Ondo State Coastal region. Bio. Sci. Res. Commu. 16: 33-39.

AOAC (2005). Official method of analysis Association of analytical Chemist. Wash. Dc, $15^{\text {th }}$ ed. 11-14.

Dee AK (1989). Environmental chemistry. Second ed. pp. 164-272.

Deuzuane J (1979). Handbook of drinking water quality. Indiana Univ. Press pp. 3-17.

Egila JN, Nimyel DN (2002). Determination of trace metal speciation in sediments from some Dams in Plateau State. J. Chem. Soc. Nig. 27: 21-75.

Environmental Protection Agency (E.P.A.) (1976). Quality Criteria for Water Use. E.P.A, 440, 1a-76-023, Environ. Agency, Wash.

Forstner U, Wittlmann GTW (1979). Metal Pollution in the aquatic environment, Berlin, Spinger-Verlag.

Ipinmoroti K, Oshodi O (1993). Determination of Trace Metals in fish, associated Wanted and Soil Sediments fresh fish ponds. Discovery innovates 5:138.
Nwajei GE, Gagophien PO (2000). Distribution of heavy metals in the sediments of Lagos Lagoon, Pak. J. Sc. Ind. Res. 43:338-340.

Oluduro AO, Adewoye BI (2007). Efficiency of moringa Oleifera Sead extract on The microflora of surface and ground water J. plant Sci. 6: 453-438.

Steel RGD, Torrie JA (1960). Principles and procedures for statistics. Mc graw-Hill, London p. 45.

WHO (1982). Guideline for drinking water quality $2^{\text {nd }}$ Ed. Recommendation. World Health Organization general 1: 30-113.

Vogel I (1970). A text book of inorganic analysis published by Harley and Sons, $4^{\text {th }}$ Ed. p.148. 